Огляди літератури, оригінальні дослідження, погляд на проблему

УДК 616.89-008.454-092-054.72

DOI 10.11603/1811-2471.2016.v0.i4.7071

\title{
ВІДМІННОСТІ ПРОЯВІВ ДЕПРЕСИВНИХ РОЗЛАДІВ У ЕМІГРАНТІВ З УРАХУВАННЯМ ГЕНЕЗУ ПАТОЛОГІЇ (ПСИХОГЕННОГО, ЕНДОГЕННОГО, ОРГАНІЧНОГО)
}

\author{
(С). П. Венгер \\ ДВНЗ «Тернопільський державний медичний університет імені І. Я. Горбачевського мОз України»
}

\begin{abstract}
РЕЗЮМЕ. Проведене дослідження соціально-психологічних, феноменологічних, клініко-психопатологічних відмінностей депресивних розладів у емігрантів з урахуванням ґенезу патології органічного, ендогенного та психогенного характеру. Використано клініко-психопатологічний, психометричний, статистичний методи. Нами обстежено 198 емігрантів (осіб, які постійно, щонайменше протягом останнього року, проживали за межами України і на момент обстеження тимчасово перебували в Україні та планували найближчим часом повернутися за кордон) яким встановлено остаточний клінічний діагноз депресивного розладу відповідно до критеріїв МКX10. Ми виділили три клінічні групи емігрантів, хворих на психогенні депресивні розлади, ендогенні та органічні. Психометричне дослідження виявило у емігрантів, хворих на депресивні розлади, виражені ознаки депресивного настрою; їм притаманні прояви адинамічної, ажитованої депресії та депресії зі страхом, причому найважчими ці прояви $\epsilon$ у хворих на органічні та ендогенні депресії. Високий рівень депресії поєднується у емігрантів 3 вираженими ознаками тривоги, як психічної, так і соматичної; ці прояви також найбільш виражені у емігрантів, хворих на органічні та ендогенні депресивні розлади. Суїцидальні спроби найрідше скоювали емігранти, хворі на психогенну депресію (2,9%). Оцінка суїцидального ризику виявила, що емігрантам притаманний суїцидальний ризик середнього ступеня.

КЛЮчОВІ СлОВА: емігранти, депресивні розлади, соціально-психологічні, феноменологічні, клінікопсихопатологічні відмінності.
\end{abstract}

Вступ. Проблема еміграції та рееміграції в Україні входить до числа найактуальніших державних та суспільних проблем. Суттю цих процесів $\epsilon$ прагнення мігрантів до благополуччя і безпеки, які між собою нерозривно пов'язані. Кількість українських мігрантів оцінюють у $15 \%$ постійного населення, і вона постійно збільшується. Еміграцію розглядають як фактор, що провокує маніфестацію або екзацербацію ендогенних психічних захворювань і призводить до виражених патоперсонологічних змін. У структурі психічних розладів у емігрантів домінують психодезадаптаційні стани, пролонгована депресивна реакція та помірний депресивний епізод. Особливості депресивних розладів у емігрантів та реемігрантів досліджені недостатньо, що унеможливлює розробку ефективних лікувальних та профілактичних заходів.

Мета роботи - дослідити соціально-психологічні та феноменологічні особливості, клінікопсихопатологічну структуру депресивних розладів у емігрантів та виявити відмінності з урахуванням органічного, ендогенного та екзогенного ґенезу патології.

06'єктом дослідження були депресивні розлади, предметом дослідження - клініко-психопатологічні, патопсихологічні та соціально-психологічні особливості депресивних розладів у емігрантів, хворих на депресивні розлади різного генезу.

Матеріали і методи дослідження. У дослідженні використано клініко-психопатологічний, психометричний, статистичний методи. Клінікопсиходіагностичне обстеження було реалізоване у формі напівструктурованого клінічного інтерв'ю з оцінкою психічного стану, симптоматики депресії та особливостей клінічних проявів захворювання. Психометричні методи включали використання шкал депресії та тривоги M. Hamilton (HRDS та HARS), опитувальника виразності психопатологічної симптоматики Symptom Check List-90Revised, шкали суїцидального ризику Г.В. Старшенбаума та шкали оцінки якості життя ВООЗ яж-26

Нами обстежено 198 емігрантів (осі6, які постійно, щонайменше протягом останнього року, проживали за межами України, на момент обстеження тимчасово перебували в Україні та планували найближчим часом повернутися за кордон) яким встановлено остаточний клінічний діагноз депресивного розладу відповідно до критеріїв MKX-10. Для забезпечення максимально точної і детальної клініко-психопатологічної оцінки особливостей депресивних проявів у емігрантів 3 урахуванням етіопатогенетичного фактора нами було виділено три клінічні групи: психогенних депресивних розладів, ендогенних депресивних розладів та депресивних розладів органічного ґенезу.

Результати й обговорення. Серед емігрантів розподіл за статтю був наступний: чоловіки складали $25,0 \%$, жінки - 75,0\%. Серед емігрантів, хворих на психогенні депресивні розлади, питома вага чоловіків і жінок склала відповідно 33,8 \% і 
Огляди літератури, оригінальні дослідження, погляд на проблему

$66,2 \%$, емігрантів, хворих на ендогенні депресивні розлади - 39,4 \% і 60,6 \%, емігрантів, хворих на органічні депресивні розлади - 41,5 \% і 58,5\%.

Середній вік емігрантів склав $(39,0 \pm 10,1)$ років. Середній вік емігрантів, хворих на психогенні депресивні розлади, склав $(39,7 \pm 8,4)$ років, емігрантів, хворих на ендогенні депресивні розлади - $(41,2 \pm 10,7)$ років, емігрантів, хворих на органічні депресивні розлади - $(39,9 \pm 8,6)$ років.

За рівнем освіти серед емігрантів 3,1 \% обстежених мають неповну середню освіту, по 6,1 \% середню і професійно-технічну, 40,8 \% - середню спеціальну, 3,1 \% - неповну вищу, 40,8 \% - вищу. 1,5\% емігрантів, хворих на психогенні депресивні розлади, мають неповну середню освіту, відповідно - 5,9 \% середню професійно-технічну освіту, 44,1\% - середню спеціальну, 2,9\% - незакінчену вищу і $41,2 \%$ - повну вищу освіту. Серед емігрантів, хворих на ендогенні депресивні розлади, неповну середню освіту мають $3,0 \%$, середню відповідно 6,1 \%, професійно-технічну - 4,5 \%, середню спеціальну - $41,0 \%$, неповну вищу $-3,0 \%$, повну вищу $-42,4 \%$. Серед емігрантів, хворих на органічні депресивні розлади, неповну середню освіту мають 4,8 \%, середню - відповідно 6,5\%, 6,6 \% і 7,8 \%, професійно-технічну - 9,7 \%, 8,2 \% і $12,5 \%$, середню спеціальну - 37,1 \%, неповну вищу $-3,2 \%$, повну вищу $-38,7 \%$.

Серед емігрантів було 34,7 \% одружених, $22,4 \%$ не одружених, 29,1 \% розлучених і $13,8 \%$ вдових. Перебували у шлюбі 41,2 \% емігрантів, хворих на психогенні депресивні розлади, ніколи не були одружені відповідно 19,1\%, розлучені відповідно 27,9 \%, вдові-відповідно 11,8\%, Серед емігрантів, хворих на ендогенні депресивні розлади, одружених було 33,3 \%, не одружених - відповідно $25,8 \%$, розлучених $-27,3 \%$, вдових $-13,6 \%$, Серед емігрантів, хворих на органічні депресивні розлади, одружених було $29,0 \%$, не одружених $-22,6 \%$, розлучених $-32,3 \%$, вдових $-16,1 \%$.
Наступним етапом роботи було вивчення особливостей перебігу психогенних депресивних розладів у емігрантів. Проблема психогенних депресивних розладів останніми роками набуває особливої актуальності у зв'язку з посиленням впливу соціально-стресового фактора. У емігрантів, крім загального соціально-стресового впливу, значну роль відіграють специфічні психосоціальні стресори, пов'язані з впливом фактора еміграції.

Виявлено, що українські емігранти стикаються зі значною кількістю соціально-стресових впливів, серед яких тяжка робота, незнання мови, нелегальне працевлаштування, самотність, труднощі у працевлаштуванні, проблеми з родичами в Україні (рис. 1).

64,8 \% емігрантів серед основних проблем зазначали незнання іноземної мови і утруднену в зв'язку з цим комунікацію, 46,9 \% - відсутність необхідних документів для проживання та роботи (нелегальне працевлаштування), 36,9% - труднощі у пошуках роботи або страх ії втратити, $76,0 \%$ - тяжку роботу (фізично чи психологічно), 44,4 \% - самотність, відсутність достатньої кількості соціальних контактів, 17,3 \% вказували на проблеми з родичами, що залишилися в Україні.

У структурі основної симптоматики депресивних розладів у емігрантів, хворих на психогенні депресії, домінують знижений настрій, виражена втомлюваність, занепад сил та втрата інтересу або задоволення від діяльності, яка раніше була приємною (ангедонія), у структурі додаткової симптоматики переважають різні види диссомній, занижена самооцінка, песимізм, почуття марності, провини, тривоги або страху.

На підставі аналізу даних клінічного дослідження було виділено основні характеристики психогенних депресивних розладів у емігрантів: відносно менша вираженість ангедонічних та астенічних проявів, більша поширеність інсомнічних, вегетосоматичних та тривожних проявів. Емігран-

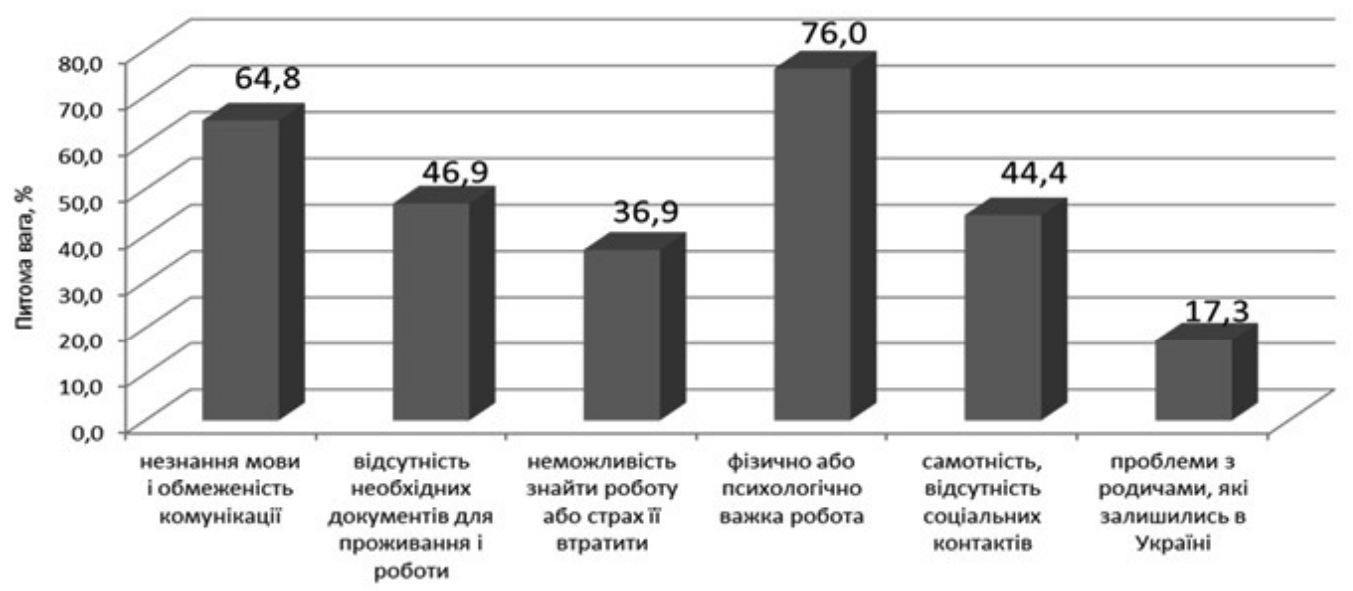

Рис. 1. Основні проблеми, з якими стикаються емігранти в країнах перебування. 
Огляди літератури, оригінальні дослідження, погляд на проблему

там, хворим на психогенні депресії, притаманні домінування тривожно-депресивного (41,2 \%) і тоскного (35,3 \%) афектів та полісиндромність клінічних проявів з переважанням атипових афективних синдромів: вегетативно-соматизованих проявів $(97, \%)$ та інсомнії $(94,1$ \%). Психометричне дослідження виявило у емігрантів, хворих на психогенні депресивні розлади, виражені ознаки депресивного настрою та тривоги (як психічної, так і соматичної); їм притаманні прояви ажитованої депресії та депресії зі страхом, причому у 32,4 \% емігрантів вираженість депресивних проявів відповідає високому рівню, а у 42,6 \% виявлені ознаки важкої тривоги. У структурі психопатологічної симптоматики у емігрантів, хворих на психогенні депресивні розлади, переважають ознаки депресії $((2,6 \pm 0,6)$ балів), тривожності $((1,7 \pm 1,1)$ балів), обсесивно-компульсивної симптоматики $((1,4 \pm 0,8)$ балів), міжособистісної сенситивності $((1,2 \pm 0,3)$ балів) та соматизації $((0,9 \pm 0,5)$ балів).

Ендогенні депресивні розлади у емігрантів характеризуються суттєвими відмінностями. Серед основної симптоматики домінують знижений настрій і ангедонія, такою ж $є$ поширеність астенічних явищ. Серед додаткової симптоматики провідні позиції займають відчуття тривоги, страху, провини або марності, занижена самооцінка і нестабільний апетит.

У емігрантів, хворих на ендогенні депресивні розлади, клініко-психопатологічна характеристика має певні відмінності. Так, у структурі клінічної симптоматики більшого поширення набувають явища ангедонії (90,9 \%) і астенії (89,4 \%), а на перший план виходить не соматовегетативна, а афективна симптоматика: відчуття тривоги, страху, провини або марності (92,4 \%), занижена самооцінка і нестабільний апетит (по 86,4 \%), думки про смерть або самогубство (78,8 \%), песимізм (75,8 \%). У структурі провідного типу афекту в цій групі домінують тоскний
(48,5 \%) та тривожно-депресивний (33,3 \%) типи, а у синдромологічній структурі зростає поширеність типових афективних синдромів, насамперед вітальної депресії (43,9 \%). У більшості (72,6 \%) емігрантів, хворих на ендогенні депресивні розлади, виявлено важку депресію, у 42,5 \% - важку тривогу, при цьому виявлені високі значення показників депресивного настрою, почуття провини, суїцидальних намірів, диссомній, зниження працездатності та активності, загальмованості, ажитації, психічної та соматичної тривоги. У структурі психопатологічної симптоматики у емігрантів, хворих на ендогенні депресивні розлади, домінують ознаки депресії $((2,8 \pm 0,4)$ балів), тривожності $((1,9 \pm 1,1)$ балів), обсесивно-компульсивних розладів $((1,5 \pm 0,7)$ балів), соматизації $((1,2 \pm 0,8)$ балів) та міжособистісної сенситивності $((1,1 \pm 0,5)$ балів).

У клініко-психопатологічній симптоматиці у емігрантів, хворих на органічні депресивні розлади, домінують знижений настрій, явища ангедонії та астенізації. 3 додаткової симптоматики найчастіше виявлялися відчуття страху, тривоги, марності або провини, занижену самооцінку і нестабільний апетит, песимізм, нездатність концентруватися і приймати рішення, думки про смерть або самогубство і порушення сну.

У емігрантів, хворих на органічні депресивні розлади, афективні порушення виражені найбільшою мірою і включають прояви ангедонії та астенізації (по 90,3 \%), відчуття страху, тривоги, марності або провини (95,2 \%), занижену самооцінку і нестабільний апетит (по 85,5 \%), песимізм (82,3 \%), нездатність концентруватися і приймати рішення (79,0 \%), думки про смерть або самогубство (74,2 \%). В структурі провідних типів афекту в цій групі переважають апатичний (33,9 \%) і тривожнодепресивний (38,7 \%) типи, а в синдромологічній структурі - анестетична депресія (61,3\%) у поєднанні з вегетосоматичними змінами $(96,8 \%)$ і асте-

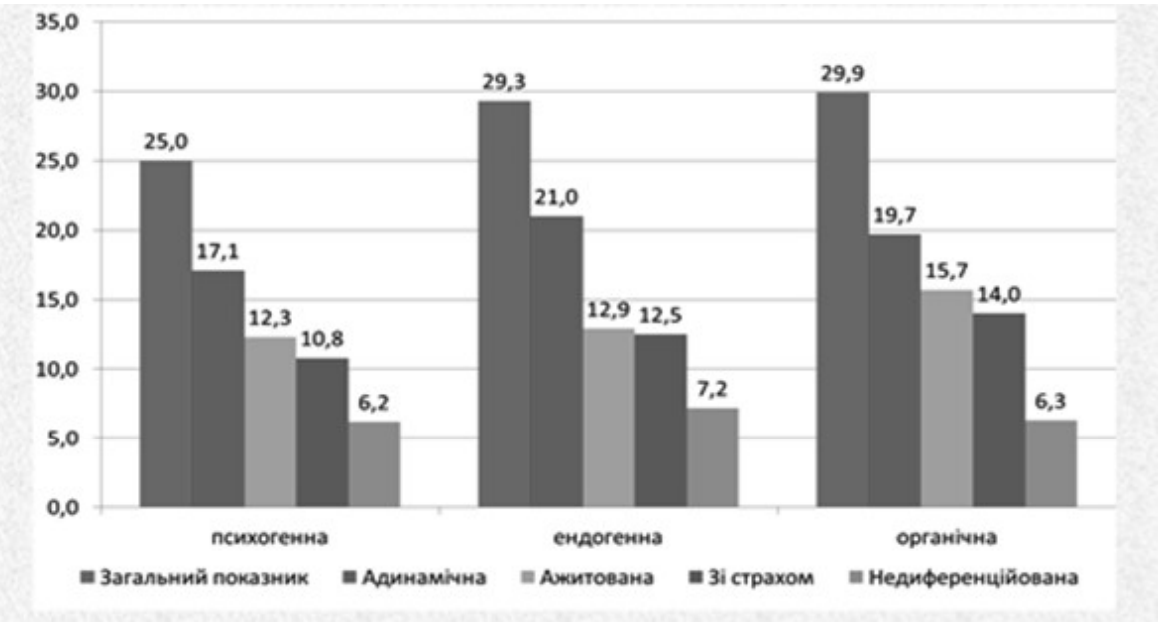

Рис. 2. Показники депресії у емігрантів за шкалою M. Hamilton. 
Огляди літератури, оригінальні дослідження, погляд на проблему

нізацією (90,3 \%). При цьому у 59,1 \% емігрантів, хворих на органічні депресивні розлади, діагностована важка депресія, у 66,2 \% - важка тривога. Для хворих цієї групи характерні виражена психічна тривога, депресивний настрій, зниження працездатності та активності, ажитація, іпохондрія та диссомнії. У структурі психопатологічної симптоматики переважають ознаки депресії $((2,9 \pm 0,4) 6 а$ лів) і тривожності $((2,0 \pm 0,7)$ балів), соматизації $((1,3 \pm 0,7)$ балів), обсесивно-компульсивних розладів $((1,5 \pm 0,5)$ балів) та міжособистісної сенситивності $((1,2 \pm 0,3)$ балів).

Психометричне дослідження виявило у емігрантів, хворих на депресивні розлади, виражені ознаки депресивного настрою; їм притаманні прояви адинамічної, ажитованої депресії та депресії зі страхом, причому найважчими ці прояви $\epsilon$ у хворих на органічні та ендогенні депресії.

Високий рівень депресії у емігрантів поєднується з вираженими ознаками тривоги, як психіч- ної, так і соматичної; ці прояви також найвираженіші у емігрантів, хворих на органічні та ендогенні депресивні розлади.

Наступним етапом роботи було вивчення суїцидальності емігрантів з депресивними розладами різного ґенезу (психогенного, ендогенного, органічного).

Серед хворих на психогенні депресії емігрантів було суттєво більше осіб з низьким суїцидальним ризиком, ніж з середнім та високим ступенями суїцидального ризику. Загалом наявність тих чи інших суїцидальних тенденцій, включаючи думки про смерть чи самогубство, суїцидальні наміри або суїцидальні дії, виявлені у переважної більшості обстежених, однак, суїцидальні дії у цій групі виявлялися рідко.

При аналізі структури суїцидальних проявів у емігрантів, хворих на ендогенні депресивні розлади, було виявлено значний відсоток хворих 3 активними суїцидальними діями, приблизно по-

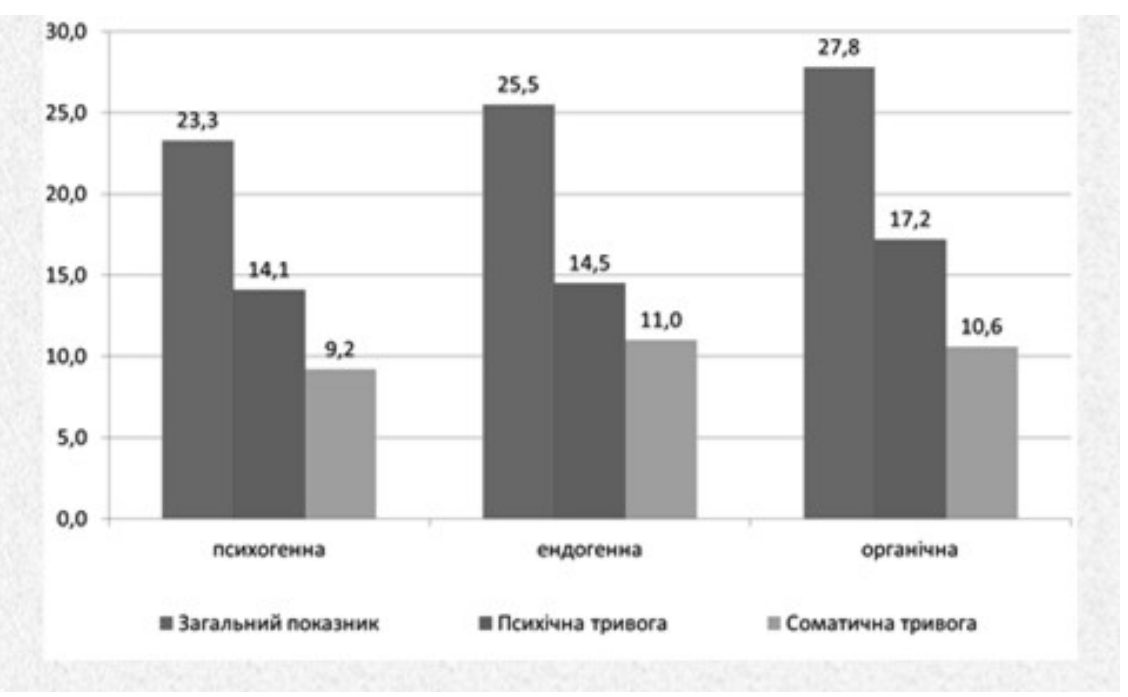

Рис. 3. Показники тривоги у емігрантів за шкалою M. Hamilton (у балах).

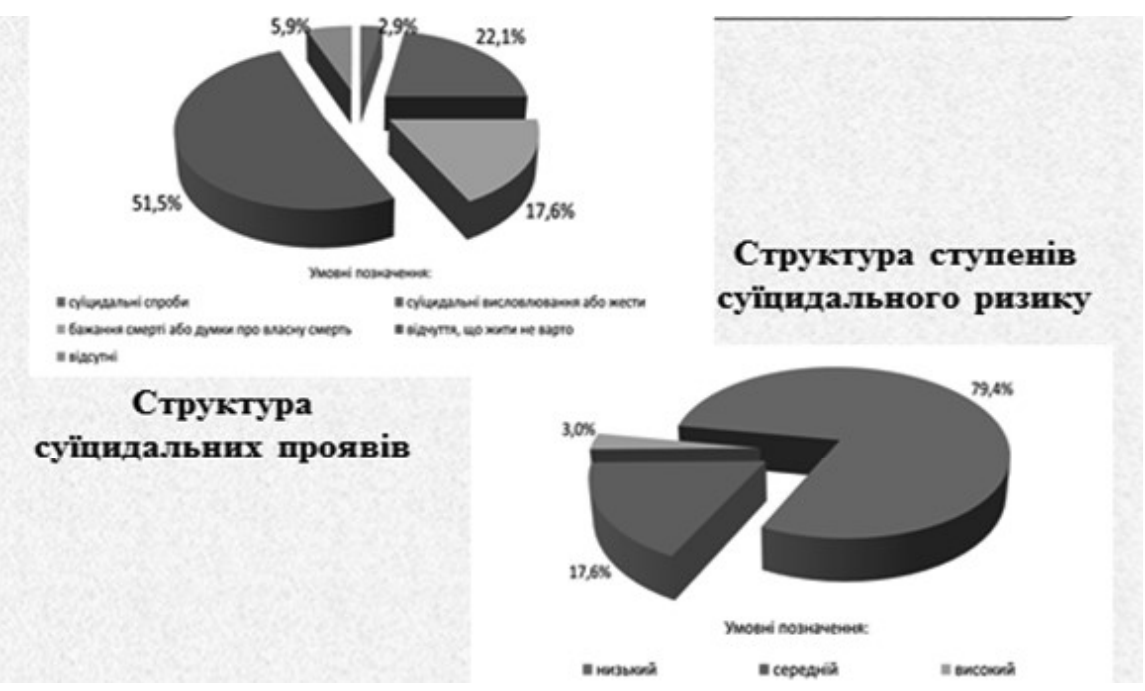

Рис. 4. Показники суїцидальності у емігрантів з психогенними депресіями. 
Огляди літератури, оригінальні дослідження, погляд на проблему

рівну розподілилася питома вага хворих з суїцидальними висловлюваннями або жестами, відчуттям, що жити не варто та бажанням смерті або думками про власну смерть. Цій групі притаманний високий ризик суїциду: у 24,2 \% хворих показники відповідали високому ступеню ризику, у 39,4\% - середньому.

При дослідженні особливостей суїцидальної поведінки емігрантів, хворих на органічні депре-

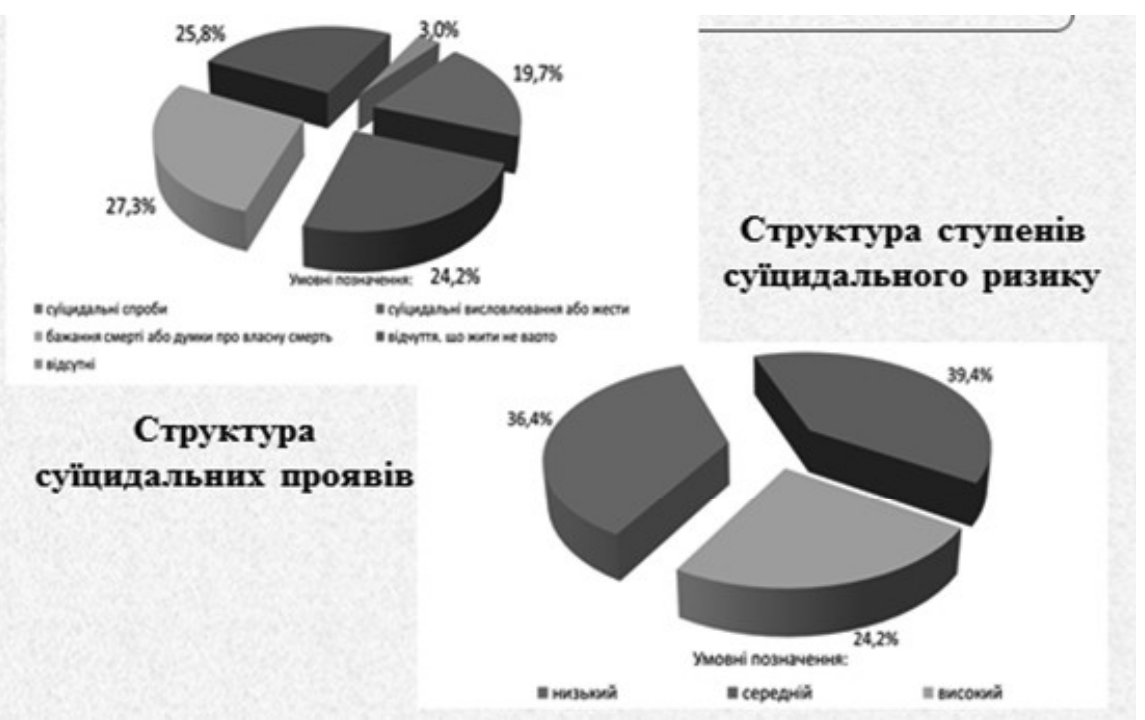

Рис. 5. Показники суїцидальності у емігрантів з ендогенними депресіями

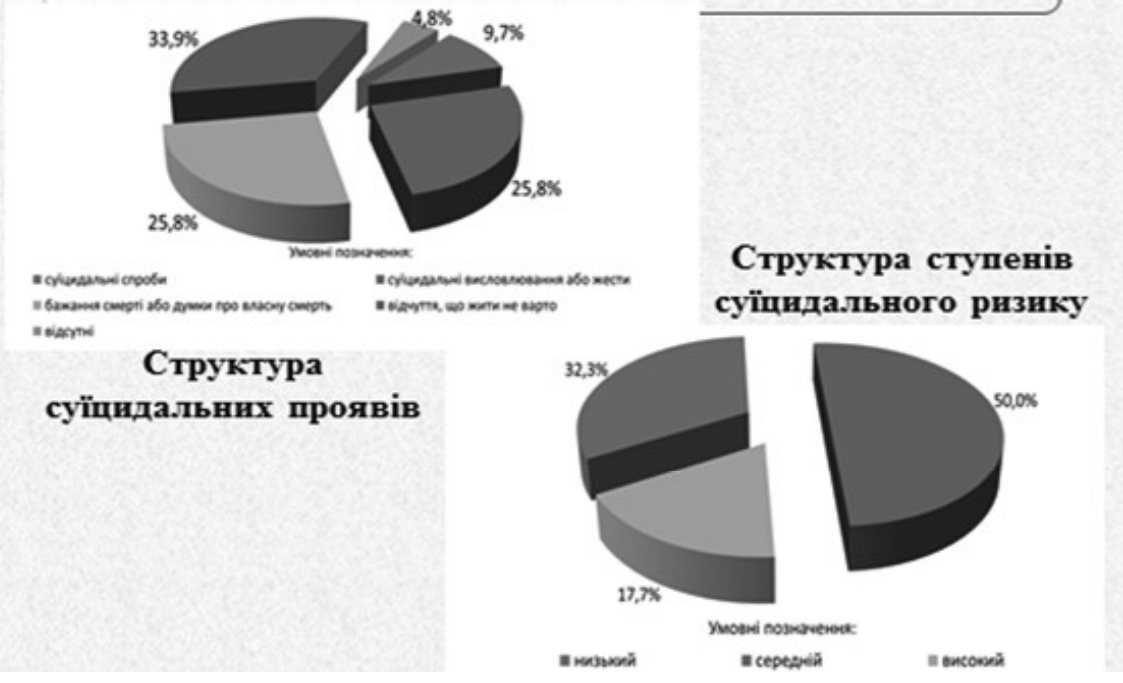

Рис. 6. Показники суїцидальності у емігрантів з органічними депресіями.

Висновки. У загальній характеристиці обстежених емігрантів переважали прояви тривоги, страху, ажитації. Аналіз домінуючого типу афекту виявив статистично значуще переважання у емігрантів тривожно-депресивного типу афекту. У синдромологічній структурі у емігрантів значуще частіше виявлялися атипові афективні синдроми, у тому числі прояви ажитації, тривоги та соматовегетативні розлади. Психометричне дослідження проявів депресії та сивні розлади, було виявлено, що у більшості хворих суїцидальні тенденції проявляються у відчуттях, що жити не варто, бажанні смерті, думках про власну смерть, суїцидальних висловлюваннях або жестах. Оцінка ступеня суїцидального ризику у емігрантів, хворих на депресивні розлади органічного ґенезу, дозволяє вважати його доволі вираженим: у 17,7 \% показники відповідали високому рівню, у 50,0\% - середньому. 
Огляди літератури, оригінальні дослідження, погляд на проблему

У синдромологічній структурі емігрантів з депресивними розладами психогенного ґенезу серед атипових депресивних синдромів найпоширенішими $\epsilon$ вегетативний і соматизований, інсомнічний та астенічний, а у структурі психопатологічної симптоматики переважають ознаки депресії, тривожності, обсесивно-компульсивної симптоматики, міжособистісної сензитивності та соматизації.

При аналізі вираженості психопатологічної симптоматики у емігрантів, хворих на ендогенні депресії, було виявлено зростання показників за шкалами депресії, тривожності, обсесивно-компульсивних розладів, соматизації та міжособистісної сенситивності. Серед типових афективних синдромів провідне місце належить вітальній депресії, значною $\epsilon$ також питома вага апатичної та анестетичної депресій. Атипові афективні синдроми представлені вегетативними і соматизованими розладами, інсомнією, астенічною депресією, психопатологічними порушеннями, ажитованою депресією, депресією зі стрибками ідей, депресивною або тривожною манією, алгічним синдромом та патохарактерологічними змінами.

Дослідження психопатологічної симптоматики у емігрантів, хворих на депресивні розлади органічного ґенезу, дозволило виявити високу вираженість депресії і тривожності, дещо меншу соматизації, обсесивно-компульсивних розладів та міжособистісної сенситивності. При аналізі синдромологічної структури депресивних розладів

\section{ЛІТЕРАТУРА}

1. Міграція в Україні: факти і цифри / Міжнародна організація з міграції. - К. : Представництво МОМ в Україні. - 2011. - 7 с.

2. Щорічна Доповідь про стан дотримання та захисту прав і свобод людини в Україні Уповноваженого Верховної Ради України з прав людини: Постанова Верховної Ради України від 05.04.2011 року № 3194-VI // Голос України. - 2011. - № 35. - с. 23-29.

3. Хармз В. А. Медико-психологические аспекты нарушения психической адаптации эмигрантов: дис. на соискание ученой степени канд. психол. наук: 19.00.04 / Вахид Аблахад Хармз; Санкт-Петербургский гос. университет. - СПб., 2000. - 186 с. органічного ґенезу у емігрантів були виявлені суттєві відмінності. Серед типових афективних синдромів домінує анестетична депресія, меншою $є$ поширеність вітальної та апатичної депресії. Серед атипових афективних синдромів переважають вегетативний i соматизований та астенічний.

Аналіз особливостей суїцидальної поведінки у емігрантів дозволив виявити високу поширеність суїцидальних проявів: наявність тих чи інших суїцидальних тенденцій виявлена у 94,1 \%, однак суїцидальні дії виявлялися відносно рідко. У структурі суїцидальних проявів характерне переважання пасивних проявів суїцидальної поведінки: відчуттів, що жити не варто, суїцидальних висловлювань або жестів, бажання смерті або думок про власну смерть. Суїцидальні спроби найрідше скоювали емігранти, хворі на психогенну депресію (2,9 \%). Оцінка суїцидального ризику з використанням шкали оцінки суїцидального ризику Г. В. Старшенбаума виявила, що емігрантам притаманний суїцидальний ризик середнього ступеня.

Перспективи подальших досліджень. Перспективи подальших досліджень, на наш погляд, полягають у розробці диференційованих підходів до лікування депресивних розладів у емігрантів з урахуванням органічного, ендогенного та психогенного ґенезу патології та виявлених особливостей.

4. Incidence of psychotic disorders in immigrant groups to the Netherlands / J. P. Selten, N. Veen, W. Feller [et al.] // British Journal of Psychiatry. - 2001. - № 178. P. 367-372.

5. The mental health of migrants / B. E. Gavin, B. D. Kelly, A. Lane [et al.] // Irish Medical Journal. - 2001. - Vol. 94. - P. 229-230.

6. Lauber C. Patterns of Psychiatric Inpatient Care in Migrants: Results from Switzerland / C. Lauber, B. Lay, W. Rossler // Swiss Medical Weekly. - 2006. - № 135. P. $50-56$.

7. Смулевич А. Б. Депрессии в общемедицинской практике / А.Б. Смулевич. - М. : Берег, 2000. - С. 19-31. 


\section{DIFFERENCES OF MANIFESTATIONS OF DEPRESSIVE DISORDERS IN EMMIGRANTS CONSIDERING DISEASE ORIGIN (PSYCHOGENIC, ENDOGENIC, ORGANIC)}

CO. P. Venher

\section{Horbachevsky Ternopil State Medical University}

SUMMARY. The conducted study of socio-psychological, phenomenological, clinical-psychopathological differences of depressive disorders in emmigrants considering the genesis of pathology of organic, endogenous and exogenous.

We used clinical-psychopathological, psychometric, statistical methods. We examined 198 emmigrants (persons permanently for at least the last year, lived outside Ukraine and at the time of the examination were in Ukraine and planned to return abroad soon) which had the final clinical diagnosis of depressive disorder according to ICD-10 criteria. For the providing of the purpose we had identified three clinical groups of emmigrants suffering from psychogenous, endogenous and organic depressive disorders. Psychometric examination in emmigrants with depressive disorders found expressed signs of depressed mood; they are characterized by manifestations of adynamic, agitated depression and depression with fear, and the most severe manifestations of these symptoms were at the patients with organic and endogenous depression. High level of depression in emmigrants is combined with expressed signs of mental and somatic anxiety; these displays are also the most expressed at emmigrants that suffering from endogenous and organic depressive disorders. More rarely suicide attempts were commited by emmigrants suffering from psychogenic depression (2.9\%). Evaluation of suicide risk found that emmigrants have medium degree risk of suicidality.

KEY WORDS: emmigrants, depressive disorders, social-psychological, phenomenological, clinical-psychopathological differences.

Отримано 27.07.2016 